\title{
Density, size, biomass, and diet of lionfish in Guanahacabibes National Park, western Cuba
}

\author{
Dorka Cobián Rojas ${ }^{1}$, Pedro Chevalier Monteagudo ${ }^{2}$, Juan J. Schmitter-Soto ${ }^{3, *}$, \\ Raúl Igor Corrada Wong ${ }^{2}$, Héctor Salvat Torres ${ }^{4}$, Erlán Cabrera Sansón ${ }^{4}$, \\ Alain García Rodríguez ${ }^{5}$, Alexis Fernández Osorio ${ }^{2}$, Leonardo Espinosa Pantoja ${ }^{6}$, \\ Delmis Cabrera Guerra ${ }^{2}$, Laura María Pantoja Echevaria ${ }^{2}$, \\ Hansel Caballero Aragón ${ }^{2}$, Susana Perera Valderrama ${ }^{7}$
}

\author{
${ }^{1}$ Parque Nacional Guanahacabibes, Centro de Investigaciones y Servicios Ambientales, Ministerio de Ciencia, \\ Tecnología y Medio Ambiente, La Bajada, 22100 Pinar del Río, Cuba \\ ${ }^{2}$ Acuario Nacional de Cuba, Calle $1^{\text {a }}$ \#6002, 11300 Playa, Havana, Cuba \\ ${ }^{3}$ El Colegio de la Frontera Sur, Av. Centenario km 5.5, 77014 Chetumal, Mexico \\ ${ }^{4}$ Formerly at Instituto de Oceanología, Ave. 1 \#18406, CP 11600 Havana, Cuba \\ ${ }^{5}$ Instituto de Oceanología, Ave. 1a \#18406, CP 11600 Havana, Cuba \\ ${ }^{6}$ Parque Nacional Cayos de San Felipe, 20100 La Coloma, Pinar del Río, Cuba \\ ${ }^{7}$ Centro Nacional de Áreas Protegidas, Calle 18A \#4114, 11300 Miramar, Playa, Havana, Cuba
}

\begin{abstract}
The Indo-Pacific lionfish Pterois volitans is an invasive species that was first recorded in the Guanahacabibes National Park (GNP), a marine protected area in western Cuba, in 2009. In order to determine the invasion progression of this species, we studied lionfish abundance, size, and diet at 6 sites in the GNP between 2010 and 2014. The species' density, biomass, and length increased over this period, probably due to the abundance of food and shelter in the GNP. Analysis of stomach contents indicated that lionfish fed primarily on fish and crustaceans; main prey were teleosts, predominantly Gobiidae, Pomacentridae, Mullidae, Labridae, Scaridae, and Grammatidae. This example of a rapid increase in an unmanaged population at the onset of invasion provides information that can be used to design a management program targeting lionfish.
\end{abstract}

KEY WORDS: Invasive species - Marine protected area $\cdot$ Reef habitat $\cdot$ Fish $\cdot$ Scorpaenidae Pterois volitans

\section{INTRODUCTION}

Invasive alien species are those introduced species that become established in natural or semi-natural ecosystems and constitute an agent of change and threat to the native species and biological diversity of the region (Mendoza \& Koleff 2014). They are typically introduced in a voluntary or accidental manner, mediated by human action (Gutiérrez 2006). In recent decades, the prevalence of invasive species has increased in both terrestrial and marine environments, reaching unprecedented levels (Meyerson \&

${ }^{*}$ Corresponding author: jschmitt@ecosur.mx
Mooney 2007). The main environmental impacts caused by these species are degradation of habitats, ecosystem imbalances, displacement and extinction of native flora and fauna, disruption of trophic structure, facilitation of subsequent invasions, and disease transmission (Gutiérrez 2006, Pyšek \& Richardson 2010). Populations of invasive species may actually increase faster and achieve higher densities in the invaded area than in their original habitat (Cox 2004). The reasons for the success of these biological invasions are not simple; they depend on the traits of the ecosystems themselves (e.g. habitat complexity;

() The authors 2016. Open Access under Creative Commons by Attribution Licence. Use, distribution and reproduction are unrestricted. Authors and original publication must be credited. 
Alexander et al. 2015), as well as on the inherent characteristics of the invading species (Mendoza \& Koleff 2014). Studies of biological invasions have a long tradition; however, literature on the subject has only increased significantly since the 1990s (Pyšek \& Richardson 2010). From this perspective, invasion biology is still a very young discipline (Pyšek \& Hulme 2009).

The establishment of Indo-Pacific lionfish Pterois volitans populations in the western Atlantic is the utmost example of a marine fish invasion (Ruiz-Carus et al. 2006). Schofield (2010) described the timing of the invasion. In Cuba, lionfish were first recorded in 2007 off the north coast east of Havana and in the southeast near Santiago (Chevalier et al. 2008). Since that time, lionfish have thoroughly and swiftly invaded the area, taking only $1.5 \mathrm{yr}$ to reach the westernmost tip of Cuba. The first sightings of lionfish occurred in Guanahacabibes National Park (GNP), western Cuba, in 2009. This invader can now be found in mangroves, seagrass prairies, and coral (Cobián et al. 2013). As observed elsewhere in the region, this invasion success is attributable to its dispersal mode, fecundity, and feeding habits, as well as a lack of natural predators (Layman \& Allgeier 2012). Darling et al. (2011) and Morris (2009) suggest that the biological and ecological characteristics of lionfish have allowed their populations to achieve higher densities in invaded regions than in their native habitats; e.g. in the Bahamas, the species has reached densities >0.039 ind. $\mathrm{m}^{-2}$ (Green \& Côté 2009), much higher than e.g. in their native Palau (0.000022 ind. $\mathrm{m}^{-2}$; Grubich et al. 2009).

Ours is the first study related to lionfish autoecology in western Cuba. This research is relevant not only because of its novelty for the area, but also because there are few (if any) cases where this type of research has been conducted in strictly non-fished areas. In the GNP, the ecosystem is healthy and wellconserved; richness is high for corals, fishes, and other groups (Cobián \& Chevalier 2009). Similarly, coral reefs in GNP lack any human impact since no commercial or recreational fishing is practiced in the area, and there is no pollution. The complete absence of management against lionfish in GNP (until 2015) makes these data an important reference for comparisons throughout the region.

The aim of this article was to determine the progression of density, biomass, and individual size of lionfish in GNP between 2010 and 2014. Compared to the invasion patterns of lionfish in other countries (Morris \& Akins 2009, Schofield 2010, Green et al. 2012), we believe that the favorable conditions of this area have allowed a significant increase in the lionfish population.

\section{MATERIALS AND METHODS}

\author{
Study site
}

GNP was established as a marine protected area in 2001 and encompasses 39830 ha (including land) in the westernmost region of Cuba, from Cabo Corrientes $\left(21^{\circ} 45^{\prime} \mathrm{N}, 84^{\circ} 30^{\prime} \mathrm{W}\right)$ to the site known as Verraco $\left(21^{\circ} 91^{\prime} \mathrm{N}, 84^{\circ} 61^{\prime} \mathrm{W}\right)$. The fringing coral reefs in GNP form a single terrace, with isolated coral heads but no well-defined crest. The sandy terrace ends at 12 to $20 \mathrm{~m}$ at a deep drop-off, which is composed of a varied and often quite complex architecture. Orbicella, Agaricia, Porites, and Siderastrea dominate the coral community (González-Ferrer et al. 2007).

\section{Underwater visual censuses and lionfish sampling}

Underwater visual censuses were conducted at 6 sites (Fig. 1) during Dec 2010, Sep 2011, Apr 2012, Jun 2013, and Feb 2014 in the front reef, from the edge of the drop-off to $25 \mathrm{~m}$ along the wall. Sampling habitats were classified as drop-off (Cuevas de Pedro, Encanto, Yemaya and Uvero Quemado) or spur-andgroove (Veral and Verraco). All surveys were conducted between 15 and $25 \mathrm{~m}$ depth. At every site, 6 linear transects (50 m long, $2 \mathrm{~m}$ wide) were surveyed, according to Brock (1954). Individual lionfish were carefully sought in cracks, caves, and hollows. The size of every lionfish sighted was visually estimated to the nearest $\mathrm{cm}$, and the total weight of individuals was calculated employing length-weight equations obtained for Cuban waters (P. Chevalier unpubl. data), equation parameters $a=0.012$ and $b=3.017$. We calculated the density (ind. $\mathrm{m}^{-2}$ ) and biomass $\left(\mathrm{g} \mathrm{m}^{-2}\right)$ of lionfish for every transect and averaged these variables for every site.

Lionfish were collected at 8 sites in June 2013 and June 2014 (Fig. 1), following sampling and processing protocols outlined by Chevalier et al. (2014). Specimens were collected with hand nets or spears. Dissections were performed on 411 freshly caught specimens. Individual prey items in lionfish stomachs were identified to the lowest taxon possible; fish identification was based on Guitart (1985) and $\mathrm{Hu}-$ mann \& DeLoach (2002); crustaceans were identified based on Martínez-Iglesias \& Gómez (1986) and Ortiz et al. (2010). 
Fig. 1. Survey and collection sites for lionfish within Guanahacabibes National Park, Cuba

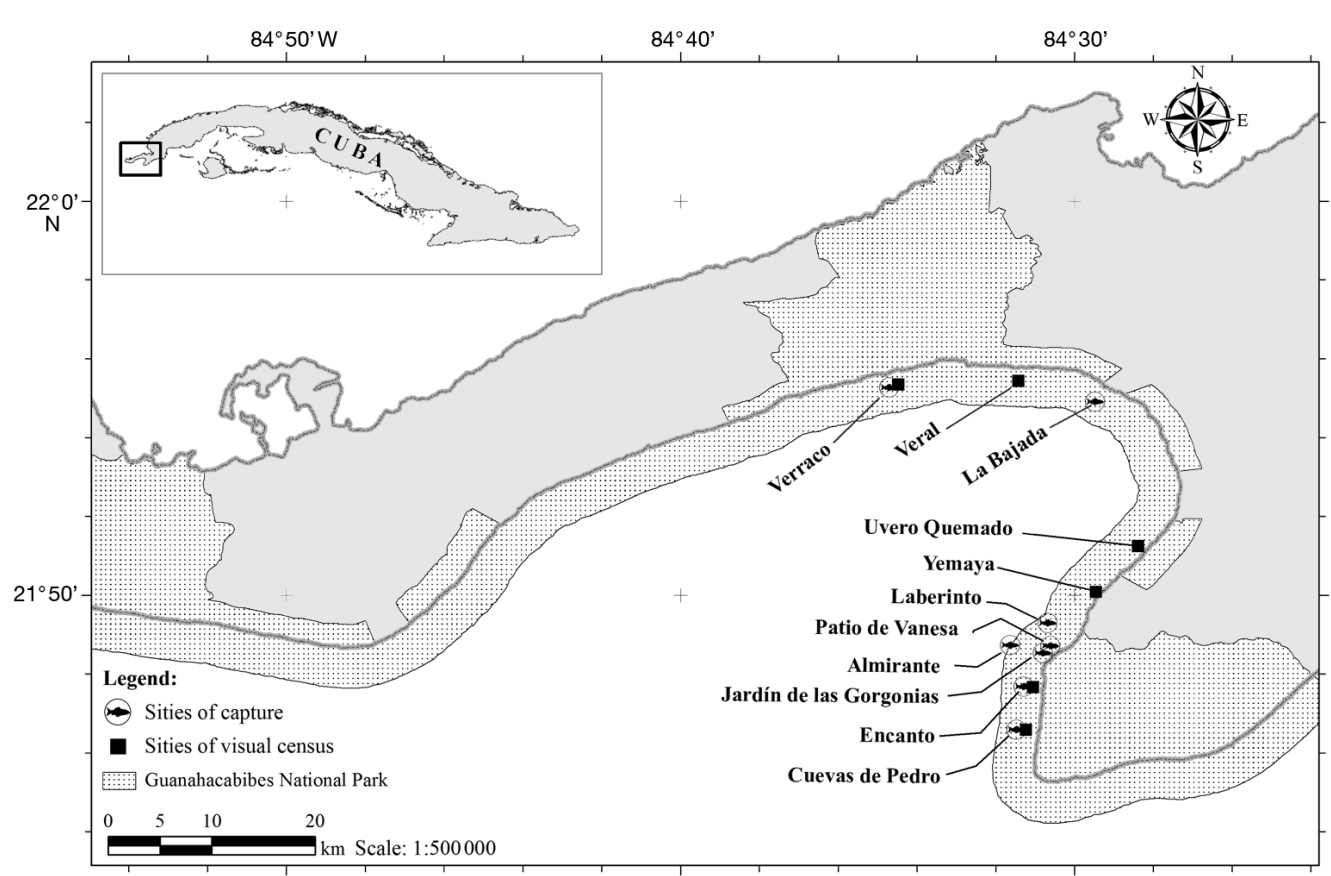

\section{Data analyses}

Data were tested for normality (Shapiro-Wilk test) and homoscedasticity (Levene's test) and were found to have a normal distribution and homogeneity of variance, so no transformation was necessary. Repeated-measures ANOVA was conducted on the density, biomass and size of lionfish by site; to determine the trend over time, an average of these variables was calculated with the values of the 6 sites for each sampling date. Significance was assessed at $\alpha=$ 0.05; a Student-Newman-Keuls test was performed when differences were significant. Statistical analyses were conducted using Statistica v. 8.0 (StatSoft).

Diet analysis combined calculations of relative abundance (number of prey items, \%N), frequency of stomachs in which prey items where present $(\% \mathrm{~F})$, and relative volume $(\% \mathrm{~V})$ into an index of relative importance (IRI; Pinkas et al. 1971), where IRI = $(\% \mathrm{~N}+\% \mathrm{~V}) \times \% \mathrm{~F}$. This was also rescaled as a percent: $\% \mathrm{IRI}=100 \times \mathrm{IRI}_{i} / \Sigma_{i}^{n} \mathrm{IRI}_{i}$ (Morato et al. 2003), where $n$ is the number of prey items and $i$ is the ith item. To explore the relationship between lionfish size versus consumption of fish and crustaceans, Spearman's non-parametric rank analysis was performed separately for $\% \mathrm{~F}, \% \mathrm{~N}$, and $\% \mathrm{~V}$.

\section{RESULTS}

Lionfish densities during the first survey in December 2010 were low $\left(<0.01\right.$ ind. $\mathrm{m}^{-2}$ ), but by Septem- ber 2011 mean densities for all GNP sites reached $\geq 0.05$ ind. $\mathrm{m}^{-2}$. Density continued to increase at all sites during the first 2 to $3 \mathrm{yr}$ after the initial invasion in 2009, leveling off around 2013. Density was highest in the drop-off habitats, at Veral and Verraco (Fig. 2). Total length of individuals also increased steadily until at least 2012 (Fig. 3) subsequently leveling off; biomass also increased, in some sites until 2013, leveling off or, in some sites, decreasing afterwards (Fig. 4). On average, density, biomass, and size increased significantly during the first years of the invasion; afterwards density decreased and the other variables leveled off (Fig. 5).

Of the 411 lionfish stomachs examined, 67 (16.3\%) were empty. A total of 54 prey items were identified, 35 of which could be identified to species level. Approximately $55 \%$ of the fish stomach contents could not be identified due to advanced stages of digestion (Fig. 6, Table S1 in the Supplement at www.intres.com/articles/suppl/b024p219_supp.pdf). Lionfish consumed prey belonging to 19 fish families, the most important being Gobiidae, Pomacentridae, Mullidae, Labridae, Scaridae, and Grammatidae (Fig. 7). Crustaceans included Decapoda, Stomatopoda, and Mysida. Mollusks consisted only of Cephalopoda.

For crustaceans, abundance, biomass, and frequency were negatively correlated with lionfish size $(\% \mathrm{~N}$ : $\mathrm{r}_{\mathrm{S}}=-0.137, \mathrm{p}=0.005 ; \% \mathrm{~F}: \mathrm{r}_{\mathrm{S}}=-0.138, \mathrm{p}=0.004 ; \% \mathrm{~V}$ : $\left.r_{S}=-0.091, p=0.050\right)$, whereas there was no significant correlation between lionfish size and fish consumption $\left(\% \mathrm{~N}: \mathrm{r}_{\mathrm{S}}=-0.008, \mathrm{p}=0.867 ; \% \mathrm{~F}: \mathrm{r}_{\mathrm{S}}=-0.052\right.$, $\mathrm{p}=0.290 ; \% \mathrm{~V}: \mathrm{r}_{\mathrm{S}}=-0.008, \mathrm{p}=0.867$ ) (Fig. 8). 

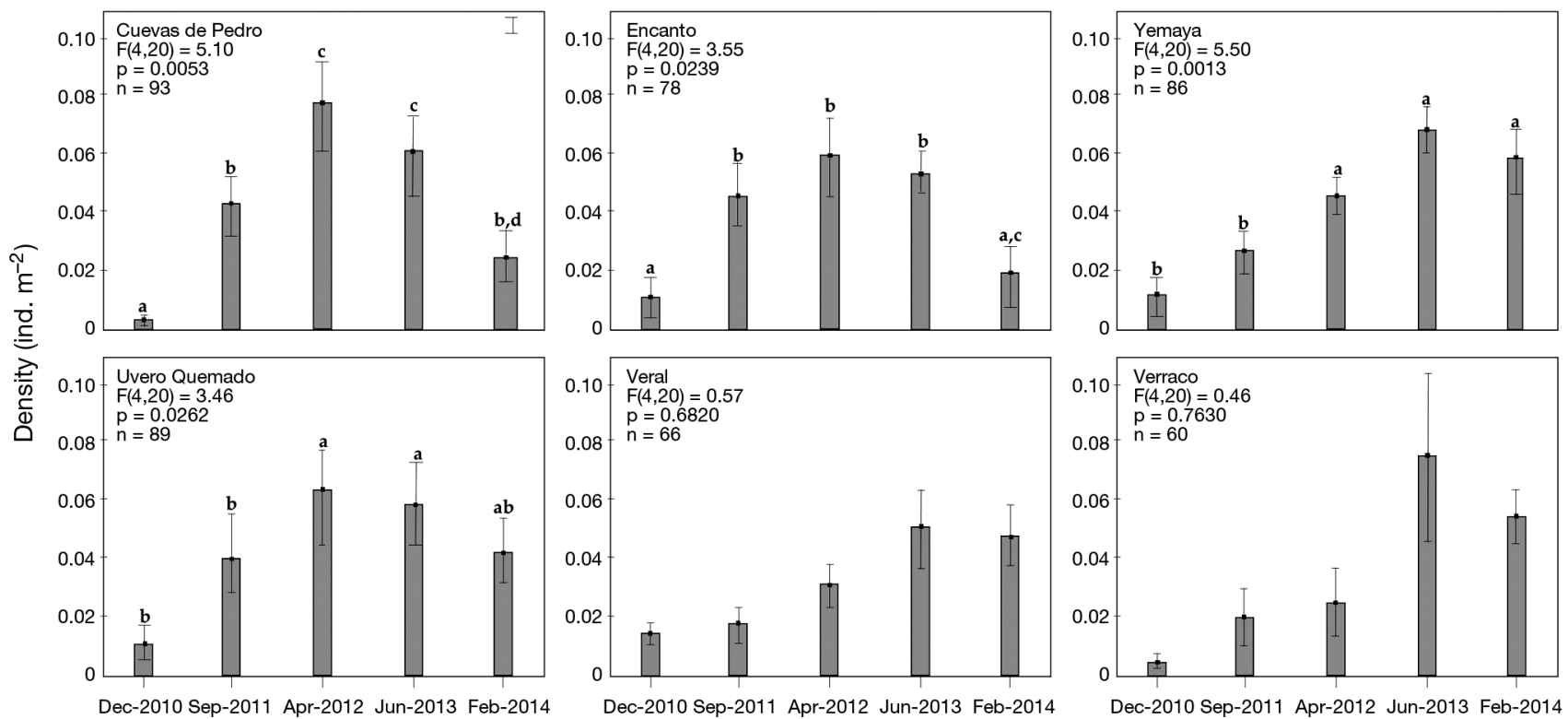

Fig. 2. Mean $( \pm \mathrm{SD})$ lionfish density at 6 sites in Guanahacabibes National Park, Cuba, determined through surveys carried out between 2010 and 2014. Lowercase letters above the bars indicate homogeneous groups found by the SNK test
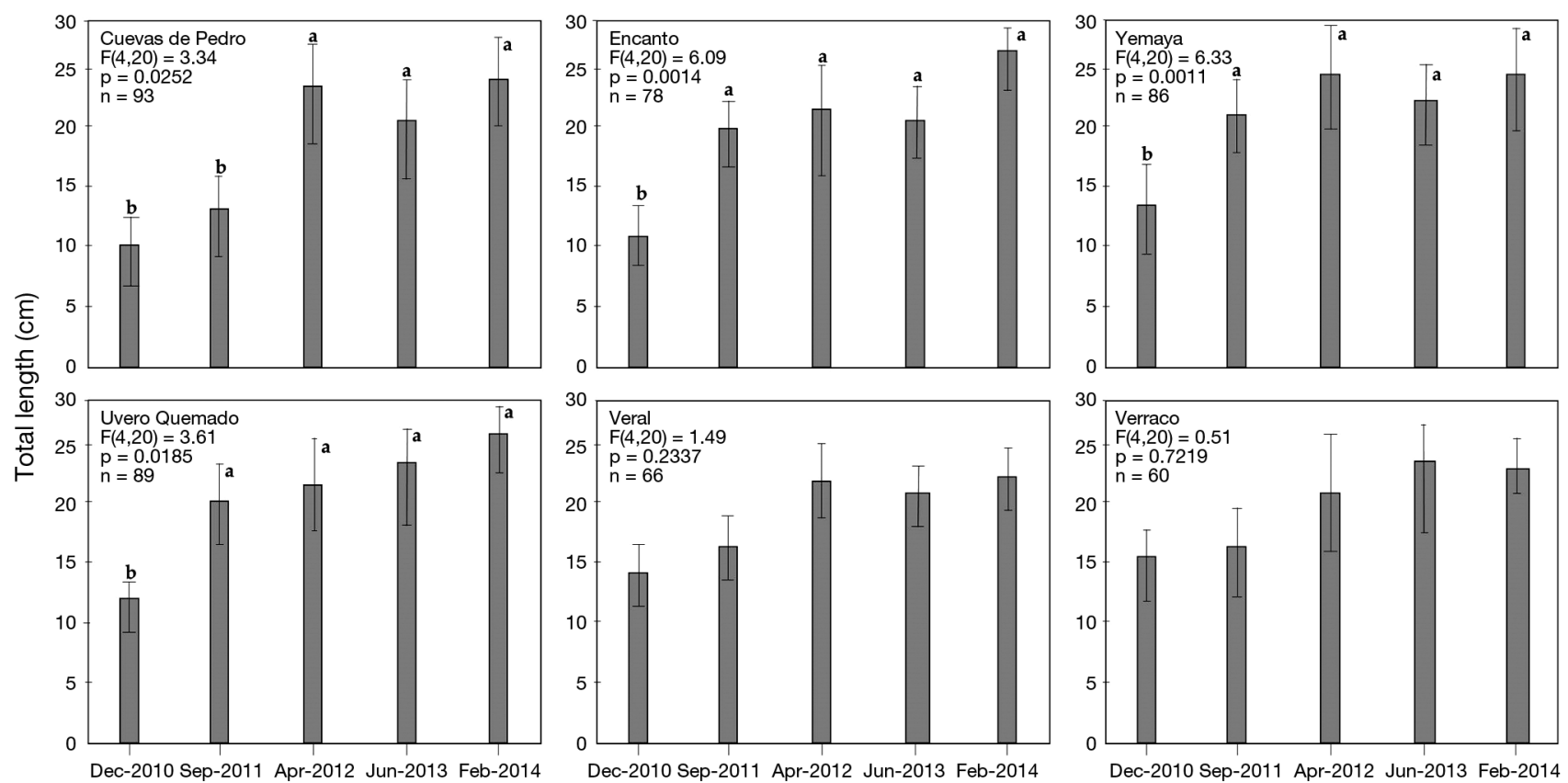

Fig. 3. Mean $( \pm \mathrm{SD})$ total length of lionfish at 6 sites in Guanahacabibes National Park, Cuba, determined through surveys carried out between 2010 and 2014. Lowercase letters above the bars indicate homogeneous groups found by the SNK test

\section{DISCUSSION}

Initial lionfish density in the GNP in February 2010 was very low compared to regions on the northern coast of Cuba at that time, such as Santa Lucía $(0.005$ to 0.017 ind. $\mathrm{m}^{-2}$ ), Sabana-Camagüey (0.032 to 0.042 ind. $\mathrm{m}^{-2}$ ), and Bahía de Puerto Padre (0.021 to 0.088 ind. $\mathrm{m}^{-2}$ ) (Chevalier et al. 2013). However by 2013, overall density in GNP (0.031 ind. $\left.\mathrm{m}^{-2}\right)$ was higher than that of the other locations (Chevalier et al. 2013), probably due to the isolation of the GNP from most human impacts and the absence of active management against lionfish. Additional factors that likely contributed to the success of the lionfish invasion in this region include the structural complexity of local reefs (which provide abundant shelter and prey) and 

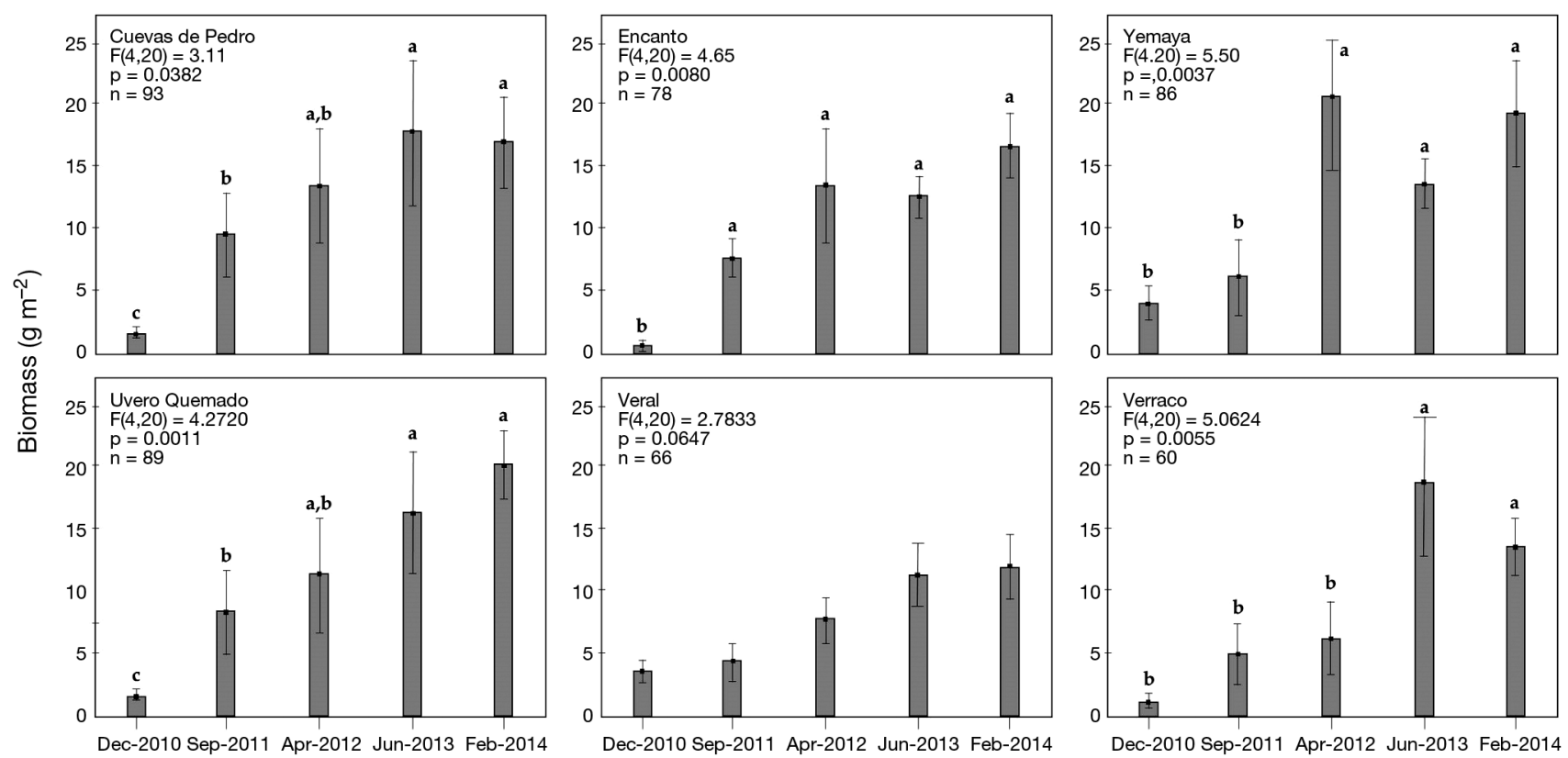

Fig. 4. Mean $( \pm \mathrm{SD})$ biomass of lionfish at 2 sites in Guanahacabibes National Park, Cuba, during surveys carried out between 2010 and 2014. Lowercase letters above the bars indicate homogeneous groups found by the SNK test
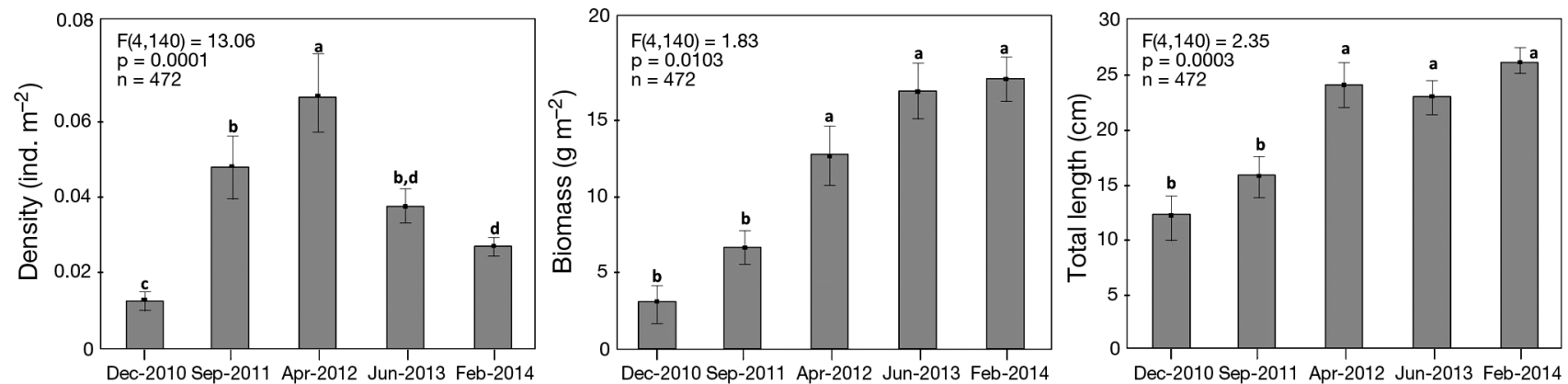

Fig. 5. Mean $( \pm \mathrm{SD})$ density, biomass, and total length of lionfish at 6 sites sampled at Guanahacabibes National Park, Cuba. Lowercase letters above the bars indicate homogeneous groups found by the SNK test

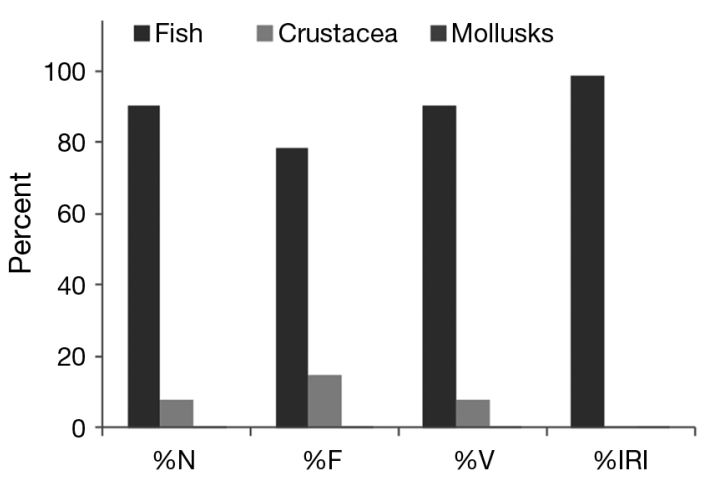

Fig. 6. Main prey groups of lionfish diet in Guanahacabibes National Park, Cuba. \%N: relative abundance by number of prey individuals; \%F: frequency of stomachs in which prey was present; \%V: relative volume or biomass; \%IRI: index of relative importance rescaled to percentage

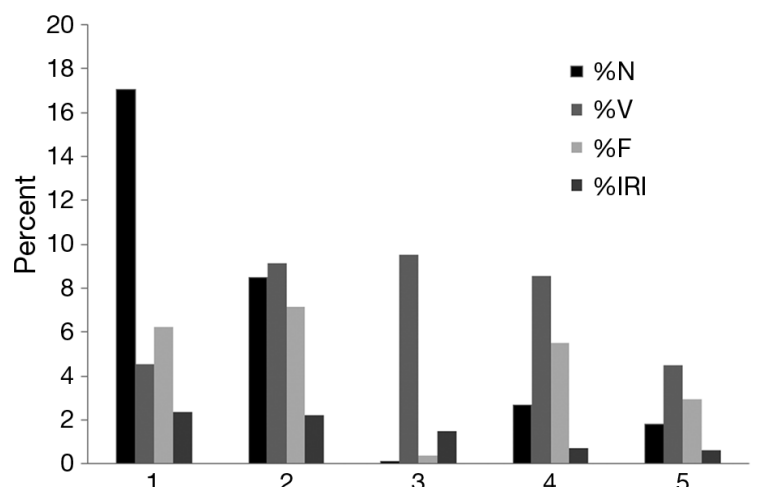

Fig. 7. Trophic spectrum of lionfish, showing fish families dominant in its diet at Guanahacabibes National Park, Cuba. \%N: relative abundance by number of prey individuals; \%F: frequency of stomachs in which prey was present; $\% \mathrm{~V}$ : relative volume or biomass; \%IRI: index of relative importance rescaled to percentage. 1: Gobiidae, 2: Pomacentridae, 3: Mullidae, 4: Labridae and 5: Scaridae 


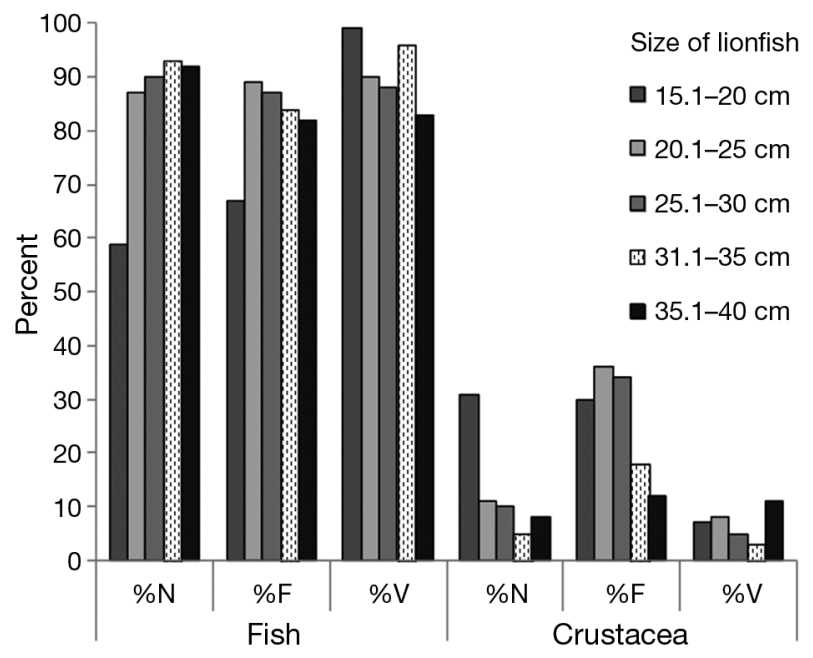

Fig. 8. Fish and crustacean consumption by lionfish size class at Guanahacabibes National Park, Cuba. \%N: relative abundance by number of prey individuals; \%F: frequency of stomachs in which prey was present; \%V: relative volume or biomass

the strict regulations of the GNP that prohibit any fishing activity (except scientific collecting). The management of Jardines de la Reina National Park in central southern Cuba is as strict as in GNP; however, it includes regular campaigns targeted at catching lionfish. Other regions in Cuba are much more accessible to artisanal fishing.

Núñez-Lara \& Arias González (1998) suggested that topographical complexity was the single most important factor affecting the reef fish community in the southern Mexican Caribbean. Cobián et al. (2011) evaluated the complexity of the substrate at the same sites surveyed in the present study; their results showed that the drop-off habitat had a high cover of live coral and greater structural complexity consisting of cavities, caves, crevices, shelves, and tunnels, providing fishes with a wide panoply of shelter. In line with this, in our study we found higher density and biomass of lionfish in this habitat. The drop-off habitat allows lionfish to remain aggregated in the same structure and refuge during the day. Adult lionfish exhibit high site fidelity (Morris 2009). This behavior could influence the high densities observed (Fishelson 1997), at least in the drop-off habitat; in the spur-and-groove habitat where structural complexity is lower, density was lower as well, and no aggregation of individuals was observed. These results are consistent with Fishelson (1997), who suggested that the density of lionfish could be influenced by local factors such as the availability of shelters and the structural complexity of the habitat. Another aspect to consider is the chronology of the invasion. The earliest sightings of lionfish in GNP occurred in late 2009 in the southeast of the Guanahacabibes peninsula. In this area, the dominant habitat is drop-off, which provides favorable conditions for lionfish populations to establish and rapidly increase during the first $3 \mathrm{yr}$ of the invasion. The population then expanded westward, following the trend of the general lionfish dispersal in Cuba (Chevalier et al. 2013).

There was no evidence of predation on lionfish in the GNP reefs, in spite of a high density and biomass of large carnivorous fishes (Cobián et al. 2011). According to Hackerott et al. (2013), the presence of predators does not appear to be a limiting factor for lionfish populations in the Caribbean. Hackerott et al. (2013) found high densities of lionfish on reefs that also supported large populations of potential predators, such as in the Jardines de la Reina National Park in Cuba, which has the highest biomass of fishes in the Caribbean but also high densities of lionfish, similar to those found in the Mesoamerican reef where predators are less common.

With regard to the size of lionfish, most of the population in GNP is composed of large adults, with a higher proportion than in other areas of Cuba and the Caribbean (Sabido Itzá et al. 2011, Chevalier et al. 2013, de León et al. 2013). Our study design did not include surveys of shallower areas, which might explain why we did not observe juveniles. Claydon et al. (2012) suggest that lionfish generally prefer to settle in shallow habitats before moving to deeper reefs as they grow. A related factor may be the absence of mangrove and seagrass ecosystems in our study area; in GNP the coast consists of sandy beaches, rocky coastline, and cliffs. Mumby et al. $(2004,2007)$ and Barbour et al. (2010) suggest that lionfish use mangrove systems as breeding sites. In GNP, mangroves are located north of the park, where juvenile lionfish may be more likely to occur.

The density of lionfish in GNP in 2013 was 0.031 ind. $\mathrm{m}^{-2}$, similar to published records for the Bahamas (0.039 ind. $\mathrm{m}^{-2}$; Green \& Côté 2009) and North Carolina (0.040 ind. $\mathrm{m}^{-2}$; Morris 2009). These densities are much higher than in their natural range, such as New Caledonia (0.000026 ind. $\mathrm{m}^{-2}$; Kulbicki et al. 2012), and may be related to the availability of food and shelter in these newly occupied areas. Morris (2013) stated that the success of the lionfish invasion can be attributed largely to its broad diet and extensive habitat preferences. Its rapid expansion in the Atlantic and the Caribbean could also be due to a more traditional reason for the success of invasive species: the absence of natural enemies that co-evolved with them in their original range as predators, parasites, or pathogens 
(Liu \& Stiling 2006) that normally control the population growth of these species.

Layman \& Allgeier (2012) considered lionfish to be an opportunistic generalist. However, we found that in GNP, they occupy a rather narrow trophic nichemore as a specialist piscivore (especially in larger size classes), similar to that described by Green et al. (2012) for lionfish in the Bahamas. The fish families best represented in its diet are also those most abundant in these reefs (Cobián \& Chevalier 2009, Cobián et al. 2011). Gobies, damselfishes, and wrasses are closely associated with the bottom, making them an ideal prey. Among gobies, Coryphopterus spp. were the most abundant prey in the GNP. These gobies tend to concentrate at specific points in the reef, facilitating hunting with a lower energy cost. Layman \& Allgeier (2012) suggest that lionfish may select their fine-scale habitat based on prey density.

Juveniles of commercially important species such as Mycteroperca spp., Epinephelus spp., and Lutjanus spp. were not among the most relevant prey items, probably because their nursery sites (mangrove and seagrass prairies) are not present in GNP. In contrast, Morris \& Akins (2009), found juveniles of Epinephelus striatus in several Bahamian biotopes. Future studies on lionfish in the GNP should include mangrove and seagrass habitats, in order to obtain a more complete picture of the impact of lionfish in this area.

Our results confirm information obtained so far in the Caribbean for this species, and suggest that the impact of lionfish on its prey increases as the lionfish grow in size and population. It is feared that this invader may adversely affect the diversity of smallsized fishes in GNP, as found by Green et al. (2012) in Bahamian reefs. The situation at GNP represents perhaps one of the clearest pictures of unmanipulated local invasion dynamics of lionfish, given the lack of management actions to date. A permanent extraction program to mitigate the invasion undertaken by GNP managers in collaboration with local communities, tourism workers, and environmental specialists, can be monitored using the information presented here as a reference.

Acknowledgements. We thank the staff of the diving resort Gaviota María la Gorda-Cabo de San Antonio, fishermen from La Bajada, and specialists at GNP for hospitality and additional records. Alfonso Aguilar-Perera, Consuelo AguilarBetancourt and Miguel Ruiz-Zárate critically revised the manuscript, as did also 5 reviewers and the editor, all of whom we deeply thank. Gabriel Cruz-Ruiz assisted in processing the figures. Field work was supported by the Global Environment Fund. The article is part of a $\mathrm{PhD}$ thesis by D.C.R., who received a grant by the Mexican Consejo Nacional de Ciencia y Tecnología.

\section{LITERATURE CITED}

Alexander ME, Kaiser H, Weyl OLF, Dick JTA (2015) Habitat simplification increases the impact of a freshwater invasive fish. Environ Biol Fishes 98:477-486

Barbour AB, Montgomery ML, Adamson AA, Díaz-Ferguson E, Silliman BR (2010) Mangrove use by the invasive lionfish Pterois volitans. Mar Ecol Prog Ser 401:291-294

Brock VJ (1954) A preliminary report on a method of estimating reef fish populations. J Wildl Manag 18:297-308

Chevalier PP, Gutiérrez E, Ibarzabal D, Romero S, Isla V, Calderín J, Hernández E (2008) Primer registro de Pterois volitans (Pisces: Scorpaenidae) para aguas cubanas. Solenodon 7:37-40

Chevalier P, Cabrera E, Caballero H, Corrada R, Fernández A, Cobián D, García A (2013) Distribución, abundancia y relaciones ecológicas del pez león (Pterois volitans/miles: Scorpaenidae) en Cuba. Proc $66^{\text {th }}$ Gulf Caribb Fish Inst 2013, Corpus Christi, TX

Chevalier P, Caballero H, Fernández A, Corrada R, Álvarez JA (2014) Protocolo para el estudio del pez león (Pterois spp.) en Cuba. In: Hernández-Zanuy AC, Alcolado PM (eds), Métodos para el estudio de la biodiversidad en ecosistemas marinos tropicales de Iberoamérica para la adaptación al cambio climático. Instituto de Oceanología, Havana, p 260-265

Claydon JAB, Calosso MC, Traiger SB (2012) Progression of invasive lionfish in seagrass, mangrove and reef habitats. Mar Ecol Prog Ser 448:119-129

Cobián D, Chevalier PP (2009) Evaluación de las asociaciones de peces de los arrecifes coralinos del Centro Internacional de Buceo María la Gorda, Parque Nacional Guanahacabibes, Cuba. Rev Cienc Mar Cost 1:111-125

Cobián D, Claro R, Chevalier PP, Perera S, Caballero H (2011) Estructura de las asociaciones de peces en los arrecifes coralinos del Parque Nacional Guanahacabibes, Cuba. Rev Cienc Mar Cost 3:153-169

Cobián D, Perera S, Pérez A, Aguilar S and others (2013) Caracterización de los ecosistemas costeros al norte del Área Protegida de Recursos Manejados Península de Guanahacabibes, Cuba. Rev Cienc Mar Cost 5:37-55

Cox GW (2004) Alien species and evolution: the evolutionary ecology of exotic plants, animals, microbes, and interacting native species. Island Press, Washington, DC

Darling ES, Green SJ, O'Leary JK, Côté IM (2011) IndoPacific lionfish are larger and more abundant on invaded reefs: a comparison of Kenyan and Bahamian lionfish populations. Biol Invasions 13:2045-2051

de León R, Vane K, Bertuol P, Chamberland VC, Simal F, Imms E, Vermeij MJA (2013) Effectiveness of lionfish removal efforts in the southern Caribbean. Endang Species Res 22:175-182

> Fishelson L (1997) Experiments and observations on food consumption, growth and starvation in Dendrochirus brachypterus and Pterois volitans (Pteroinae, Scorpaenidae). Environ Biol Fishes 50:391-403

González-Ferrer S, Caballero H, Alcolado PM, Jiménez A, Martín F, Cobián D (2007) Diversidad de corales pétreos en once sitios de buceo recreativo de 'María la Gorda', Cuba. Rev Inv Mar 28:121-130

> Green SJ, Côté IM (2009) Record densities of Indo-Pacific lionfish on Bahamian coral reefs. Coral Reefs 28:107

Green SJ, Akins JL, Maljković A, Côté IM (2012) Invasive lionfish drive Atlantic coral reef fish declines. PLoS One $7: \mathrm{e} 32596$ 
Grubich JR, Westneat MW, McCord CL (2009) Diversity of lionfishes (Pisces: Scorpaenidae) among remote coral reefs of the Palau Archipelago. Coral Reefs 28:807

Guitart D (1985) Sinopsis de los peces marinos de Cuba, tomos I y II: $2^{\text {nd }}$ edn. Editorial Científico-Técnica, Havana

Gutiérrez F (2006) Estado de conocimiento de especies invasoras: propuesta de lineamientos para el control de los impactos. Instituto de Investigación de Recursos Biológicos Alexander von Humboldt, Bogotá

Hackerott S, Valdivia A, Green SJ, Côté IM, Cox CE, Akins L, Bruno JF (2013) Native predators do not influence invasion success of Pacific lionfish on Caribbean reefs. PLoS One 8:e68259

Humann P, DeLoach N (2002) Reef fish identification. Florida, Caribbean, Bahamas, 3rd edn. New World, Jacksonville, FL

Kulbicki M, Beets J, Chabanet P, Cure K and others (2012) Distributions of Indo-Pacific lionfishes Pterois spp. in their native ranges: implications for the Atlantic invasion. Mar Ecol Prog Ser 446:189-205

Layman CA, Allgeier JE (2012) Characterizing trophic ecology of generalist consumers: a case study of the invasive lionfish in the Bahamas. Mar Ecol Prog Ser 448:131-141

Liu H, Stiling P (2006) Testing the enemy release hypothesis: a review and meta-analysis. Biol Invasions 8:1535-1545

Martínez-Iglesias JC, Gómez O (1986) Los crustáceos decápodos del golfo de Batabanó: Brachyura. Poeyana 332: $1-91$

Mendoza R, Koleff P (2014) Especies acuáticas invasoras en México. Comisión Nacional para el Conocimiento y Uso de la Biodiversidad, Mexico City

Meyerson LA, Mooney HA (2007) Invasive alien species in an era of globalization. Front Ecol Environ 5:199-208

Morato T, Solá E, Grós MP, Menezes G (2003) Diets of thornback ray (Raja clavata) and tope shark (Galeorhinus galeus) in the bottom long line fishery of the Azores, northeastern Atlantic. Fish Bull 101:590-602

Morris JA Jr (2009) The biology and ecology of invasive Indo-Pacific lionfish. PhD thesis, North Carolina State University, Raleigh, NC

Morris JA Jr (2013) El pez león invasor: guía para su control y manejo. Gulf Caribb Fish Inst Spec Publ Ser 2,

Editorial responsibility: Christine Paetzold,

Oldendorf/Luhe, Germany
Marathon, FL

Morris JA Jr, Akins JL (2009) Feeding ecology of invasive lionfish (Pterois volitans) in the Bahamian archipelago. Environ Biol Fishes 86:389-398

Mumby PJ, Edwards AJ, Arias-González JE, Lindeman KC and others (2004) Mangroves enhance the biomass of coral reef fish communities in the Caribbean. Nature 427:533-536

> Mumby PJ, Hastings A, Edwards HJ (2007) Thresholds and the resilience of Caribbean coral reefs. Nature 450: 98-101

> Núñez-Lara E, Arias González E (1998) The relationship between reef fish community structure and environmental variables in the southern Mexican Caribbean. J Fish Biol 53:209-221

Ortiz M, Lalana R, Varela C (2010) Guía ilustrada para la identificación de los camarones comerciales (Decapoda, Dendrobranchiata, Penaeoidea) de Cuba. Rev Cubana Cienc Biol 22:53-66

Pinkas L, Oliphant MS, Iverson ILK (1971) Food habits of albacore, bluefin tuna and bonito in California waters. Calif Dep Fish Game Fish Bull 152:1-182

Pyšek P, Hulme P (2009) Invasion biology is a discipline that's too young to die. Nature 460:324

Pyšek P, Richardson DM (2010) Invasive species, environmental change and management, and health. Annu Rev Environ Resour 35:25-55

> Ruiz-Carus R, Matheson RE, Roberts DE, Whitfield PE (2006) The western Pacific red lionfish, Pterois volitans (Scorpaenidae), in Florida: evidence for reproduction and parasitism in the first exotic marine fish established in state waters. Biol Conserv 128:384-390

Sabido Itzá MM, Gómez Poot JM, Medina Quej A, García Rivas MC, Hadad López W (2011) Dinámica poblacional del pez león (Pterois volitans) en el Parque Nacional Arrecifes de Xcalak (PNAX), Quintana Roo, Caribe mexicano. Proc $64^{\text {th }}$ Gulf Caribb Fish Inst 64:67-74

Schofield PJ (2010) Update on geographic spread of invasive lionfishes (Pterois volitans [Linnaeus, 1758] and P. miles [Bennett, 1828]) in the Western North Atlantic Ocean, Caribbean Sea and Gulf of Mexico. Aquat Invasions 5: S117-S122

Submitted: July 2, 2015; Accepted: March 7, 2016 Proofs received from author(s): April 12, 2016 